\title{
The representation of health and illness in lifestyle propaganda posters of the Polish People's Republic as a method of promoting cultural norms
}

Rafał Nowakowski

Poster Museum in Wilanów, Warsaw, Poland

\begin{abstract}
The poster, as a historical object, functions on several different levels. It is a testimony of social life and popular culture, an example of the evolution of graphic design, but also a document of visual communication. Under capitalism the poster has become an instrument of advertising. However, in the specific geopolitical conditions of post-war Poland, advertising was replaced by propaganda. Instead of evolving communications aimed at consumers, development focused on propaganda or the promotion of public actions. This form of propaganda pertained not only to political questions, but also to issues of social advocacy. In this way, health and hygiene literacy building entered the public discourse.

While usually initiated by the state, these efforts were often embraced by artists. The confluence of art and social advocacy was evident in efforts such as the activity of the Polish Anti-tuberculosis Society - founded before Wold War II, in anti-alcohol or anti-nicotine campaigns, or in sexual education campaigns, such as those building awareness of venereal diseases. Such initiatives contributed to the development of active civic attitudes among Polish graphic artists, who frequently became involved in social advocacy efforts.

At the same time, Polish poster art obtained a unique position in the world, in which the artistry and individualism of the artist overshadowed the functional aspects of applied art. The result of this was the development of a sophisticated and original form of art, combining the latest achievements of visual communication with social engagement and public health advocacy. In this way, applied art was harnessed as a way of communicating positive, educational messages, attributing health promotion efforts with an artistically refined form. The ongoing project investigates the archival materials of the Wilanów Poster Museum in order to document this important aspect of social life in Poland.
\end{abstract}

KEY WORDS: propaganda posters, lifestyle, promoting cultural norms.

ADDRESS FOR CORRESPONDENCE: Rafał Nowakowski, Poster Museum in Wilanów, 10/16 Kostki Potockiego Street, Warsaw 02-958, Poland, e-mail: erefen@poczta.onet.pl

\section{AN ANTHROPOLOGY OF IMAGES}

It should be noted at the outset that this text deals with art's relationship with the social context in its broader sense, in this case health and medicine. Thus, for the purposes of this article we shall treat health and disease in the social science context as anthropological categories. Since we are dealing with the relationship of art to medicine and health education, we are interested in images of health and disease as certain aspects of symbolic human activity, as well as the appropriate response that these "signs" (pictures characterised by a message) may engender in human behaviour and social structures. A history and analysis of poster health campaigns may significantly develop our knowledge concerning the duplication of visual stereotypes, persuasion techniques, and the psychological basis underlying the manipulation of recipients. In a word, an analysis of health posters will enhance research into propaganda images used in the creation and dissemination of certain cultural norms. 
The French philosopher and historian Michel Foucault, drawing on the writings of Seneca, defined a set of actions by means of which the human individual becomes a social being. According to this theory, people gain knowledge about themselves by means of these intellectual tools. Foucault distinguishes between production techniques, the techniques of a sign system, and the techniques of power. As a fourth type, he also mentioned the so-called "techniques of self" which, as he explained: "allow individuals to carry out, by their own means or with the help of others, certain operations on their own bodies and souls, thoughts, behaviour, manners, and actions, whose goal is self-transformation in order to attain a certain state of happiness, purity, wisdom, perfection, or immortality" [1].

Based on these assumptions, maintaining one's health and cleanliness belong among the techniques ensuring an individual's dignity and the conditions for close coexistence in society. Health and hygiene, secured by specific medical rules or principles of coexistence, allow citizens and those of working age to function normally. Maintaining one's health is ensured by such secular virtues as moderation, discipline, self-control, punctuality, and respect for authority. In turn, certain types of threats prevent an individual's occupational and social activity. The most common dangers are illnesses, germs, pollution, failure to comply with health and safety regulations, addictions, infectious diseases, and industrial hazards. Thus, emphasis on hygiene became a form of propaganda for a "healthy" lifestyle from the point of view of the social structure in the industrial era.

Lifestyle fits into the broader context of specific cultural norms. According to Erving Goffman's anthropological theory [2], our social life resembles a kind of ritual or theatrical performance. Each of us has a role to play in his/her appropriate setting; also as an audience, and even props. From this point of view, being a healthy or sick member of society also constitutes a certain role in the social performance, one that follows its own rules. Goffman explains it thus:

"Status and social position are not something material that can be acquired and then shown off; rather these are models of proper behaviour, consistent, polished, and well-articulated, either fraudulently or in good faith. In any case they are something that has to be played and demonstrated, something that must be attained" [3]. Within the sphere of the stereotypes in circulation, we can say that good physical and mental health is associated with an affirmation of life, and with nature, the ability to work, innocence, joy, serenity (“joie de vivre”). An individual's social contribution depends on his/her physical health and properly functioning senses. Similarly, a sick person is one unable to work, in whom poor physical condition is combined with a specific threat or lack of foresight. Thus, illness is associated with infirmity, inability to work, dissatisfaction, but also a kind of insouciance. However, in our culture a sick person is someone who deserves help and mercy. We should also remember that illness is a kind of liberation from the dictates of the daily routine. Not without reason the French have a saying that goes: "illnesses are the travels of the impoverished". In connection with this, illness is seen in human consciousness as something somehow subversive, against the social order.

In turn, the modern science of signs and symbols has developed an unusual hypothesis. According to the concepts of structuralism, we live in a world of symbolic exchange. Images have turned into symbols, and once their meaning became permanently fused with the image - they became icons, memos, or simulacra. As a result, images no longer refer to real objects, only to each other, creating a closed, virtual world. Roland Barthes put it bluntly when he wrote: "Ancient or otherwise, mythology can only have a historical basis, because myth is a word chosen by history: it could not emerge from the very nature of things. This word is a message. So it may not be of an oral nature at all; it may take the form of a written message or presentation: a statement in writing, but also photography, film, documentary, sport, spectacle, advertising - all these may be mediums of mythical speech" [4].

Propaganda, visual or verbal, took over the role of ancient mythology and currently serves to reiterate certain superstitions or prejudices, which we generally call stereotypes. Ordinary works of propaganda nature consist of dogmatic content dressed up in a conservative, aesthetic form. Barthes distinguishes between "a language system, la langue (or its absorption of presentation methods), which I shall call object-language, because it is a language acquired by myth to construct its own system; and myth itself, which I shall call meta-language - because it's a secondary language - in which we talk about the first" [5].

Thus, the struggle to change human consciousness somewhat resembles a symbolic war, in which certain images combat or displace other images. The image (seen as a sign, and thus with a certain semantic connotation) constitutes a kind of medium of cultural norms. That is why, for example, advertising images are treated as tools of persuasion towards a certain lifestyle. Following on from this, we can conclude that the social poster as a work of applied art struggles not so much with certain habits or tendencies, but above all with the image, the norm of certain behaviour. By means of symbolic measures, the poster confronts a certain set of prejudices that can be called "stereotypes". What is more, it wages that struggle by means of stereotypes.

To summarise, it must be remembered that as a social document the poster indicates certain tendencies, but does not show the actual state of affairs (as for example a report in a newspaper). The poster is meant to constitute an example, a model of conduct, and not relate 
a particular historical event. In the years of the Polish People's Republic, the poster constituted art subordinated to propaganda campaigns. And the organisation of propaganda campaigns testified to the existence of particular social problems [6]. If Janusz Rapnicki's poster "Take care of your own health and that of the family" (published by the National Institute of Medical Publications, 1953) shows a young mother from a village reading a brochure, that does not mean that all peasants were so enlightened back then. That was merely the model of a rural mother, whereas the truth was just the opposite. Illiteracy just after World War II was almost universal. Women from the villages had to be encouraged to read by means of educational campaigns. And thanks to the talents of the artists, this was achieved in a pleasant and accessible way.

\section{MEDICAL INITIATIVES UNDER SOCIALISM}

In the social sense of applied art, aesthetics become a kind of persuasion technique or symbolic suggestion. Since man lives primarily in a world of symbols, any change in the impression images make has a direct impact on human consciousness. While these influences are highly complex and hard to track, we may easily trace the history of the technology used in aesthetic persuasion and its institutional support in the form of specialised publications.

And so, even while the war still waged, in the liberated territories a Supreme Commission for Combating Epidemics was established in Katowice in 1944, which functioned until 1947. However, in 1945 a branch of the National Institute of Hygiene resumed its operations, thanks to which so-called disinfecting stations were organised and epidemic hospitals and anti-malaria stations were opened. In 1945-1947, Provincial Information and Propaganda Offices (established by the Ministry of Information and Propaganda) were in operation, handling propaganda and public education campaigns. These offices were abolished in favour of the centralised Arts and Graphics Publishing House, which took over the production of posters [7]. In 1949 the first post-war social campaign, the First Week of Health, was initiated. That same year, the National Institute of Medical Publications was established, specialising in both professional medical publications and educational and popular science magazines. 1949 also saw the state's first campaign to combat sexually transmitted diseases - known as the "W" campaign (the Polish equivalent of the V in VD). Almost 20 years had to pass before the next campaigns of this type were undertaken [8].

In 1954 the State Sanitation Inspectorate was established to replace the former Supreme Commission for Combating Epidemics. In 1957 the Warsaw Institute of Disinfection Pest and Rodent Control was established in the capital, which continues to operate to this day. This institute was also involved in hygiene education. At the

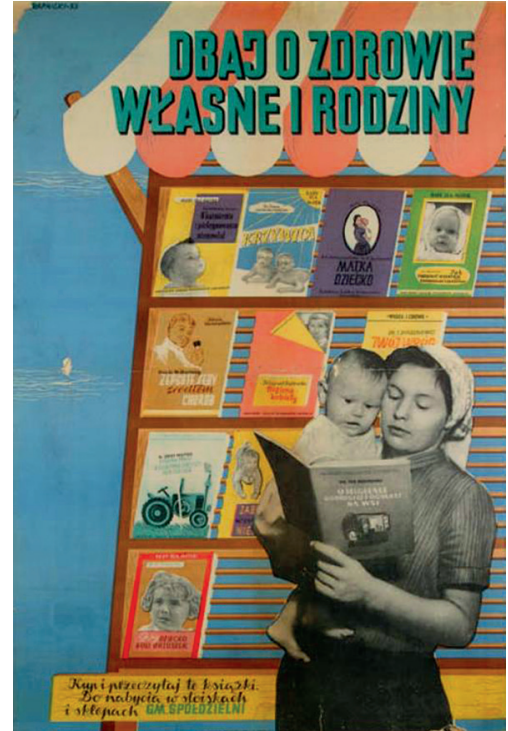

FIG. 1. Janusz Rapnicki: Keep yourself and your family healthy. Buy and read these books, 1953

same time, that legendary social organisation the Polish Red Cross was deprived of its autonomy, its assets being gradually taken over by state institutions [9].

The authors of an article on the health situation in the communist period wrote:

"A good example of state involvement in public health under the Polish People's Republic was the struggle against tuberculosis. After the war, the state took over all actions directed against this disease. Already in 1945, a Tuberculosis Section of the State Health Board was established. In March 1948, the director of the Polish Anti-Tuberculosis Institute was appointed, and the Institute was allocated significant state funding. In 1951, by decree of the President of the Council of Ministers, an Institute of Tuberculosis was established as an independent research centre overseen by the Minister of Health. One of the aims of the Institute, as described in its statute, was to best utilise 'the scientific achievements of pioneering Soviet science'. In April 1955, by decree of the Minister of Health, compulsory and free of charge BCG vaccinations were introduced, and on 22 April 1959 the Polish Parliament passed the Anti-Tuberculosis Law. The conference abstract titles of the $10^{\text {th }}$ Polish Anti-Tuberculosis Congress, held in September 1951, betray how politicised the subject of tuberculosis had become in Poland. They included: 'The struggle against tuberculosis in the six-year plan', or 'Principles of dialectical materialism applied to the fight against tuberculosis" [10]. After the Second World War, the country's disastrous health situation underwent rapid improvement thanks to technology and medical advances. The most serious health problems after the war were epidemics of infectious diseases (tuberculosis, typhoid fever) and high infant mortality. Both these phenomena were associated with the post-war upheaval, the terrible condition 


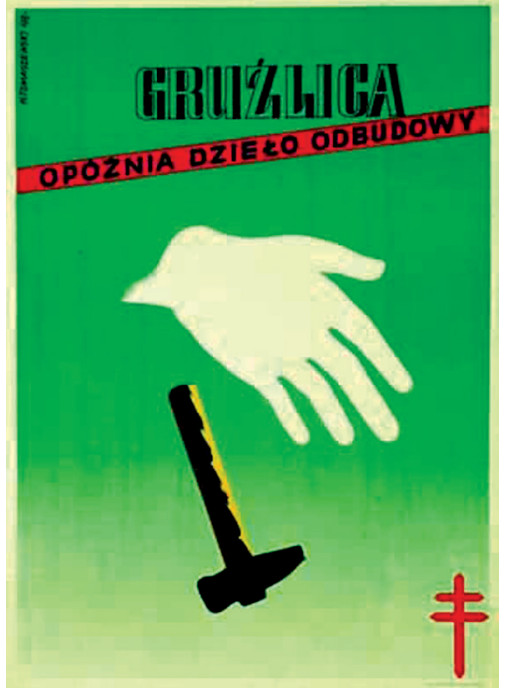

FIG. 2. Henryk Tomaszewski: Tuberculosis delays the work of rebuilding the country, 1948

of the medical infrastructure, and lack of hygiene. The state took upon itself the task of improving the health of the population through centralised, hierarchic medical institutions. Thanks to this, within 20 years the country had almost caught up with Western Europe in terms of technological progress in medicine and improved quality of life [8].

However, the growing health awareness of citizens failed to proceed at the same rate as improvements in living conditions. This poor level of awareness caused a sudden increase in diseases related to inappropriate lifestyles. Due to this, the early '70s took an unexpected turn. The mortality rate among adult citizens began to increase. But this time the main causes of disease were bad diet and harmful habits, especially alcohol and tobacco. The old model of a comfortable life turned out to be harmful to health, and people failed to see the need to take care of their health. They entrusted this task to the professional medics and institutions imposed by the higher authority, namely the state. This lack of awareness resulted in a breakdown of the overall health situation.

Partly as a response to these developments the first social campaigns began, designed to raise citizens' awareness. Chronologically, the first campaign was aimed at combating venereal diseases, and in 1968 the first posters about VD were published by the still operational WAG - Wydawnictwo Artystyczno-Graficzne (Arts and Graphics Publishing House) [7]. Two years later, in 1970 the Ministry of Health established a Venereology Institute at the Medical Academy in Warsaw. In 1971, the first exhibition of posters encouraging temperance was organised by the Social Committee Against Alcohol (established in 1959). This exhibition can be considered an imperfect prototype of social initiatives aimed at health education. In the same year, a second campaign was launched against venereal disease, organised by the
Venereal Institute of the Venereology Medical Academy. 1972 saw the establishment of the Social Committee for the Eradication of Tuberculosis and Lung Diseases, one of the first social organisations dealing with tuberculosis and probably the prototype of anti-nicotine and cancer organisations.

In 1978, the social activist Marek Kotański founded MONAR, the country's first drug treatment centre. In the early ' 80 s, other specialised drug addiction treatment centres opened, including the Society for the Prevention of Drug Abuse. Interestingly, these initiatives received government support as a result of a social initiative, with a group of high school students sending an official letter to the authorities (and hence, among others, to the Central Committee of the Polish United Workers' Party) entitled "Open Letter on drug addiction". As a result of the growing threat and social expectations, in 1985 the communist government issued the first post-war law on the prevention of drug abuse. In 1979, the Polish Anti-Smoking Society was established in place of the former Social Anti-Smoking Committee. The 1980s saw the first independent initiative dedicated to combating tobacco smoking, initiated by Professor Witold Zatoński, an oncologist treating patients with lung cancer [10].

Social service organisations and social campaigns, beginning in the " $50 \mathrm{~s}$, became increasingly bureaucratised, institutionalised, and politicised, right up to the early "70s, when the first "grassroots" social initiatives came about. It is hard to say what the actual effectiveness of these campaigns was, but it should be noted that due to the highly prestigious position of poster design, the poster actions organised were something of a conscious social advertising campaign, usually organised by state institutions. It has to be remembered that this was the only available and legal form of social activity.

\section{TECHNIQUES OF VISUAL PERSUASION}

The propaganda poster generally operated on three levels. Firstly, the early health posters were created primarily as public information campaigns for the illiterate. For many reasons, images have a greater propaganda impact than the word. But for the more enlightened, the poster also contained specific information in writing. Usually, along with a catchy slogan there was also relevant and concrete information. Finally, for those recipients with an artistic flair, the posters were designed as works of art. Serving as a good example of this may be Henryk Tomaszewski's poster "Tuberculosis delays the work of rebuilding the country" (published by the Provincial Office of Information and Propaganda, 1948), where a crippled hand evokes the broken wing of a white dove of peace, as painted by Pablo Picasso.

When it comes to the art of propaganda, we can distinguish the following basic techniques of visual persuasion. Above all it starts by building a stereotype or mental template. In general, this comes from a set of data trans- 
mitted by means of a so-called "memo", the basic unit of cultural information. Propaganda is generally based on conservative aesthetics and stereotypes, duplicated without any deeper reflection. Visual persuasion uses very specific images that $R$. Barthes calls signs. They are not meant to be aesthetically original and sophisticated, simply typical and anonymous. The use of satirical drawings, comics, and other straightforward graphic forms to transmit content creates a poster combining information and persuasion. On one hand, we have an emotional impact and on the other, common sense, rational and pragmatic arguments, such as the concept of hygiene.

According to behavioural psychology [11], to develop a specific reflex a living being needs a certain mental stimulus, disproportionate to the phenomenon itself. Then, even if that phenomenon should disappear, there will remain a reaction to the substitute stimulus. These stimuli are called positive or negative reinforcement. Briefly speaking, their action involves rewards for proper behaviour and punishments for inappropriate behaviour. As far as a definition is concerned, Przemysław Bąbel and Paweł Ostaszewski write: "positive reinforcement refers to any stimuli appearing in the aftermath of behaviour that leads to intensification of that behaviour; negative reinforcement - the stimuli that certain behaviour permits one to avoid or escape from, which also leads to an increase in the frequency of that behaviour" [12].

To achieve this positive or negative reinforcement, applied art used certain techniques of visual persuasion that we can categorise as follows:

- humour or the ridiculing of undesirable behaviour,

- deterrence, or showing the negative effects of bad habits,

- propagation of positive models, or promotion of heath and health awareness.

We may illustrate our argument with a concrete example. The first public information campaign concerned dangerous epidemics such as tuberculosis and typhoid fever. Hence the terrifying public information posters by Kazimierz Moździerz, for example "Report in confidence to the Anti-tuberculosis Clinic" (published in 1950 by the Health Department of the Katowice Provincial Council). Apart from a distinct graphic style that was intended to awaken specific associations (and the image of snake, which could scare and cause shudders of fascination), a second, less obvious layer usually contained specific information. In general, one large or several small graphic images showed specific scenes, to which a catchy slogan was attached - while in the deeper layer of the composition, specific information was added in a smaller size font.

On the other hand, sometimes the visual patterns related to specific cultural models. The poster by Jerzy Karolak "Second Health Week" (published by the Polish Red Cross, 1950) presents a typical model of the so-called "nuclear family", its socialist version, as representatives of the workers' proletariat. Here everything

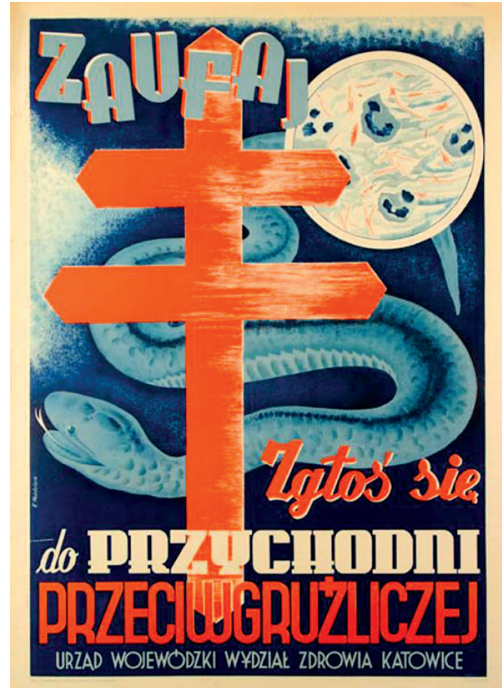

FIG. 3. Kazimierz M. Moździerz: Report in confidence to the Anti-Tuberculosis Clinic, 1950

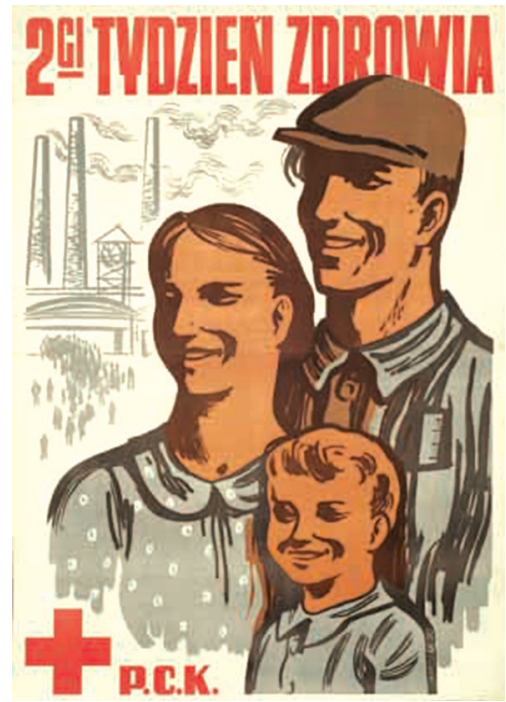

FIG. 4. Jerzy Karolak: Second Health Week, 1950

is of significance. The smiles on the tanned faces, their being partly dressed in work clothes, the standard hairstyles, and even the industrial background. Anyhow, according to a strange intention, in the classless society former proletarians were to be the new middle class, on which productivity and the status quo of the state would be based.

The poster by Marian Bogusz "Stop drinking! Join us in building a happy future" (published by the Polish Red Cross, 1951) presents the problem of alcoholism in the context of certain social norms. The alcoholic is presented here as someone who, as a result of his weak will, alienates himself from society and ceases to be a productive individual (the social value of a person is determined on the basis of his/her fitness to work). Alcoholism is a social disease, even a form of handicap, which excludes the offender from the work of building the country's 


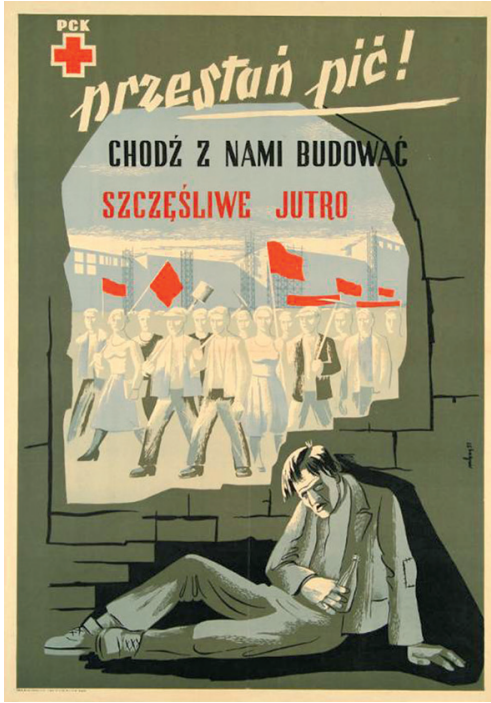

FIG. 5. Marian Bogusz: Stop drinking! Join us in building a happy future, 1951

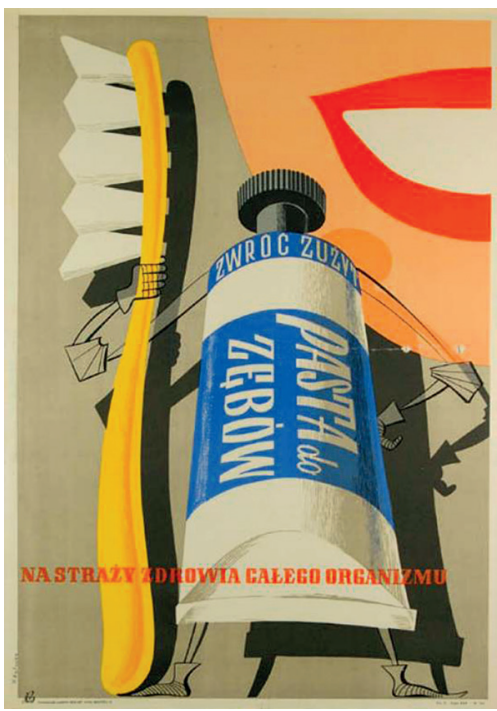

FIG. 7. Maksymilian Kałużny:Toothpaste protects the health of the whole body, 1954

future. Today we know that the psychology and sociology of addiction is actually much more complicated.

Although artistic posters are almost purely visual, they almost always contain specific information. As a result, some vital information was concealed in almost every poster from that era. Perhaps most important is the way in which that information was woven into the composition. For example, the grey letters forming the names of winter spas appear in the shadow of a large smiling snowman in Wiktor Górka’s poster "Winter holidays. Employee Holiday Fund" (published by the Arts and Graphics Publishing House, 1954).

Maksymilian Kałużny's poster “Toothpaste protects the health of the whole body" (published by the Universal Advertising Agency, 1954) uses humour in promot-

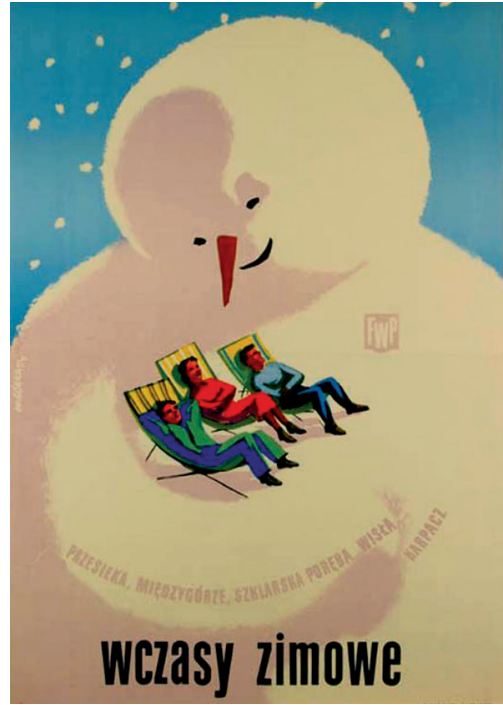

FIG. 6. Wiktor Górka: Winter holidays. Employee Holiday Fund, 1954

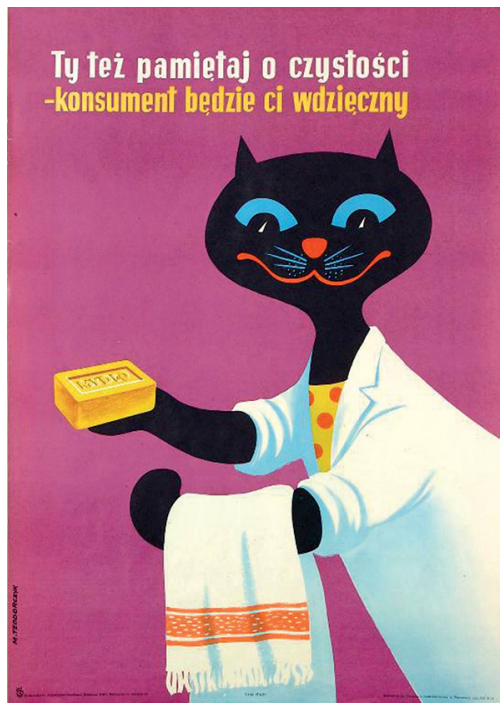

FIG. 8. Mieczysław Teodorczyk: You too remember about cleanliness, 1957

ing positive role models with regard to hygiene. In this case, the tools of cleanliness are posed as knights from the illustrations of fairy tales. It may be worth mentioning that this is in fact a commercial advert disguised as a public information poster. Under socialism, deprived of a free market, there was not supposed to be any commercial advertising, and its place was to be taken by social initiatives and posters. But in reality, things looked a little different.

Similarly, Mieczysław Teodorczyk in the 1957 poster "You too should remember about cleanliness..." (published by WAG) promotes certain patterns of behaviour (cleanliness in the workplace) by means of light satire. It is worth noting that cats are perceived as stereotype animals known for their cleanliness. 


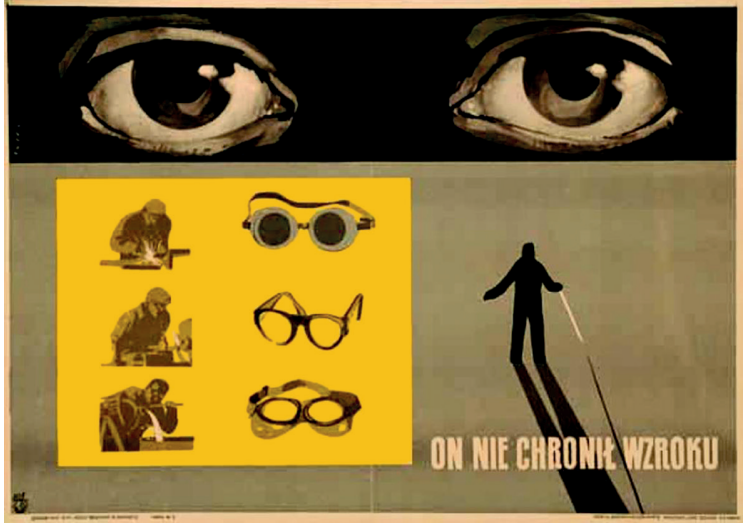

FIG. 9. Waldemar Świerzy: He forgot to protect his eyes, 1995

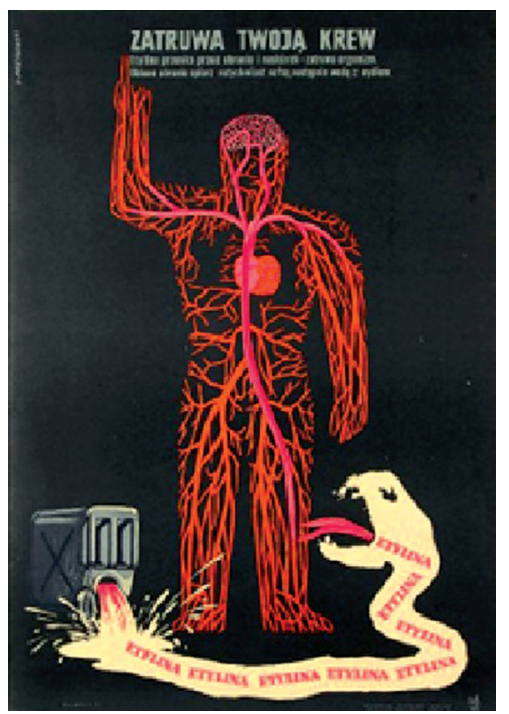

FIG. 11. Jerzy Przygodzki: Ethyl poisons your blood, 1959

Diseases and disability are treated primarily as occupational hazards, and so appear in warning posters on health and safety at work [6]. Waldemar Świerzy's poster "He forgot to protect his eyes" (published by WAG, 1955) using economical but blunt graphic elements resembling sober mug shots, tells the story of a tragic accident in a remarkably dispassionate, yet comic-style narrative.

Another poster by the acclaimed graphic designer W. Świerzy "Kill flies" (published by WAG, 1957) may be singled out for stylistic reasons. From the hygiene point of view, it presents an image of the source of all evil, germ spreading insects. The artist used a style evoking dirt: a jagged contour line, a repulsive image, and poisonous, impure colours based on associations with rot, predators, and all kinds of atavisms originating in pre-civilisation times. The names of various diseases appear on the legs of the fly.

Jerzy Przygodzki's poster "Ethyl poisons your blood" (published by WAG, 1959) presents a poisonous substance as a venomous snake. Interestingly, there are few

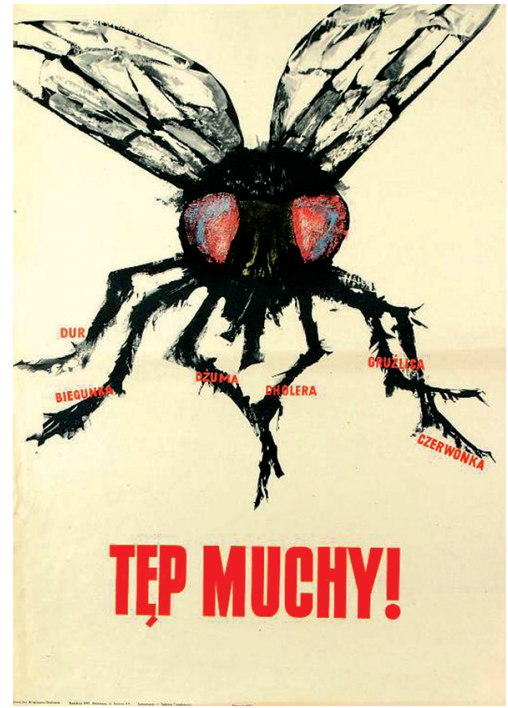

FIG. 10. Waldemar Świerzy: Kill flies!, 1957

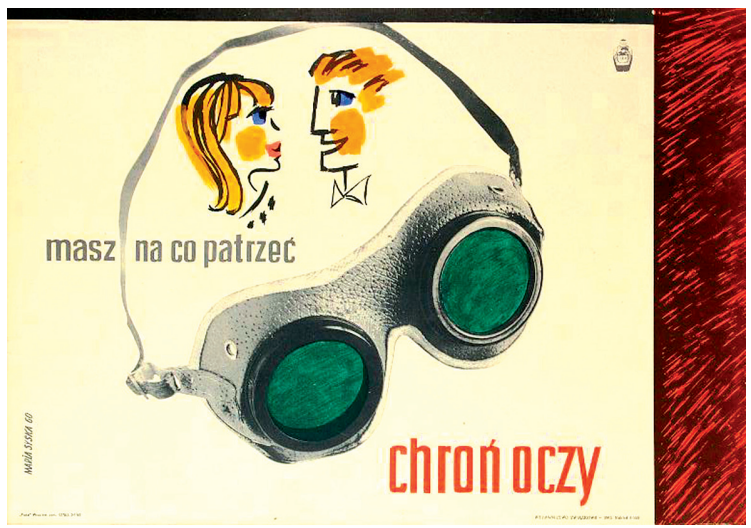

FIG. 12. Maria Syska: You've got something to look at protect your eyes, 1960

venomous snakes in Poland - so once again we are evoking atavisms common not only to all people, but also all mammals. The image is maintained in an appropriate style, the jagged edges of the snake's silhouette and the aggressive white creating a form perceived as disagreeable and unpleasant, arousing anxiety. The red nervous system is as mesmerising as it is vulnerable. It extends a hand in a gesture of surrender, and at the same time points to the inscription, like skeletons in baroque allegories of death that point to the inscription: "I was what you are; I am what you will be".

In a completely different spirit is the poster by Maria Syska "You've got something to look at - protect your eyes" (published by CRZZ - the Central Council of Trade Unions, 1959). The cheerful stylistics of the drawn genre scene contrast with the brutal immediacy of the photographed object. Interestingly, appearing here is a completely different motivation, not so much professional as emotional, intimate, and loving. 


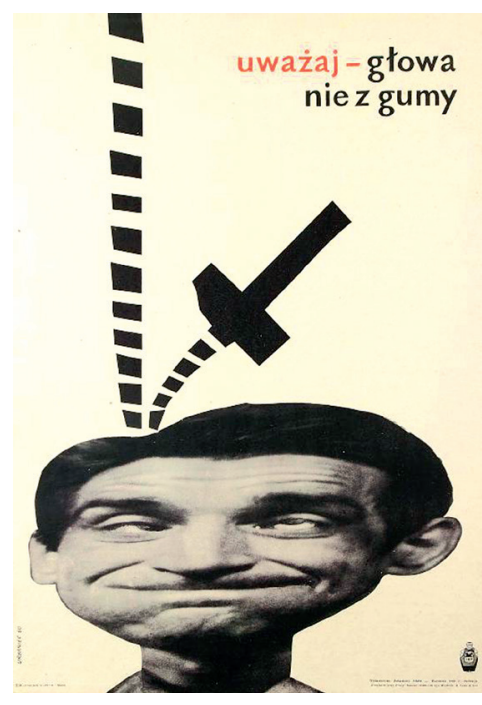

FIG. 13. Maciej Urbaniec: Take care - your head isn't made from rubber, 1960

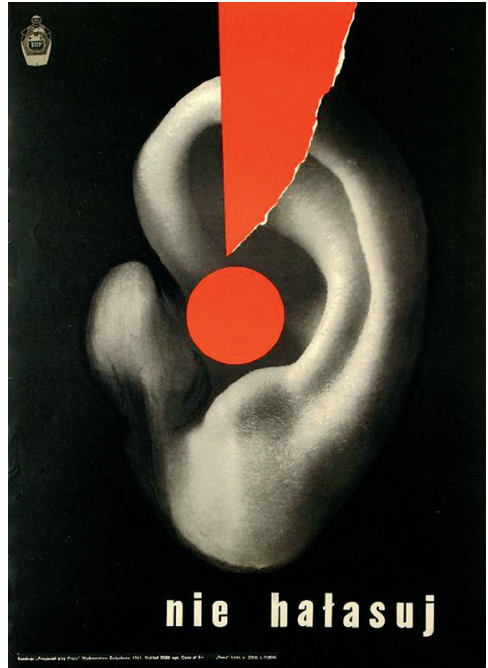

FIG. 15. Zdzisław Osakowski: Keep the noise level down, 1961

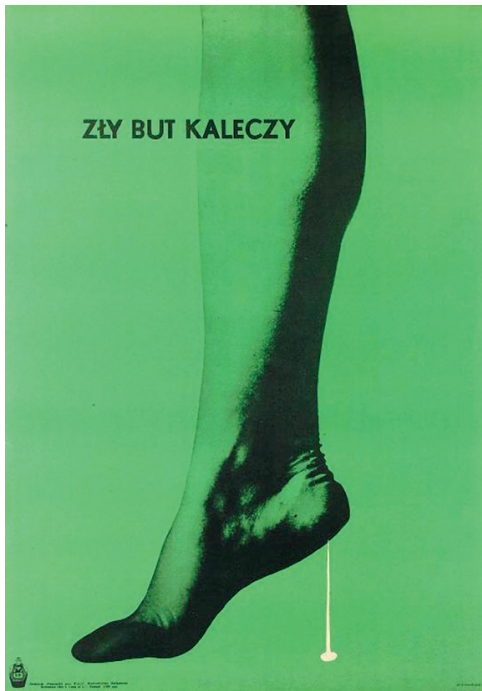

FIG. 17. Zdzisław Osakowski: Badly fitting shoes can cause injury, 1963

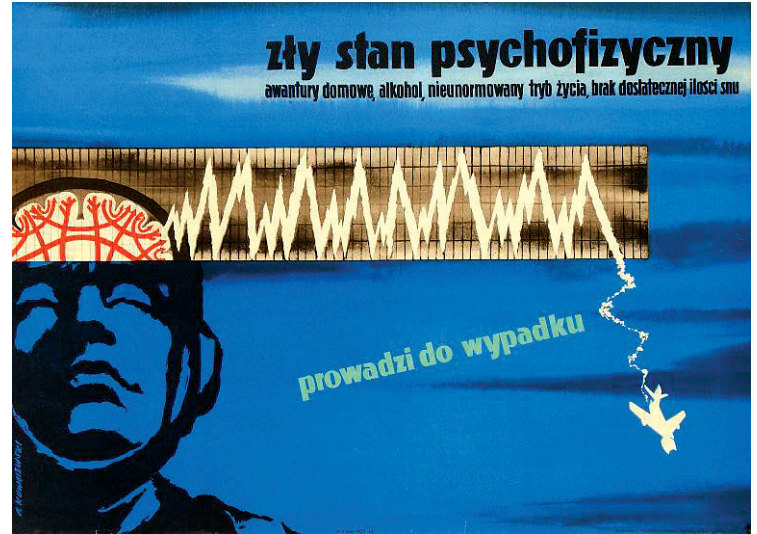

FIG. 14. Andrzej Kowalewski: Poor psychophysical condition leads accidents, 1960

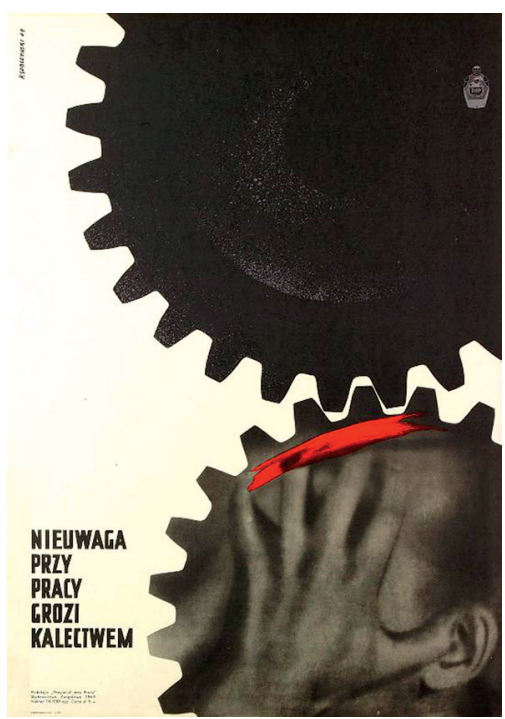

FIG. 16. Robert Sobczyński: Carelessness at work can lead to injuries, 1961

Another health \& safety poster [13] by Maciej Urbaniec "Take care - your head isn't made of rubber" (published by CRZZ, 1960) seeks to ridicule certain behaviours, inattention, negligence, or carelessness. In this way, particular anti-social (irrational) ways of behaving are shown to be unacceptable, treated with a kind of curse, which in modern society came to be replaced by ridicule, stigma, and exclusion.

Specific in its subject matter, Andrzej Kowalewski's poster "Poor psychophysical condition leads to accidents" (published by WAG, 1960) lists the social and psychological causes of poor performance: "domestic quarrels, alcohol, non-standard lifestyles, and the cancer of insufficient sleep". The message leaves no doubt that to be a good worker, you need to comply with certain norms also in your private life.

The red, torn exclamation mark placed directly over the photograph of an ear on Zdzisław Osakowski's poster "Keep the noise level down" (published by CRZZ, 1961) initiates a stage of fairly brutal experiments with photography. 


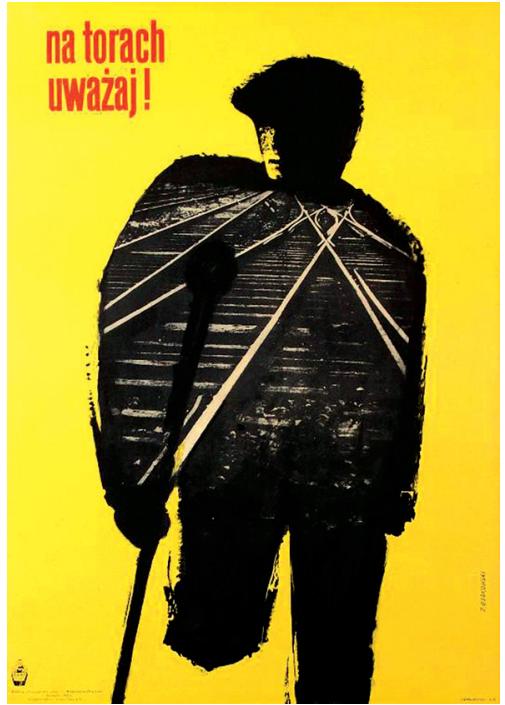

FIG. 18. Zdzisław Osakowski: Take care on the tracks, 1963

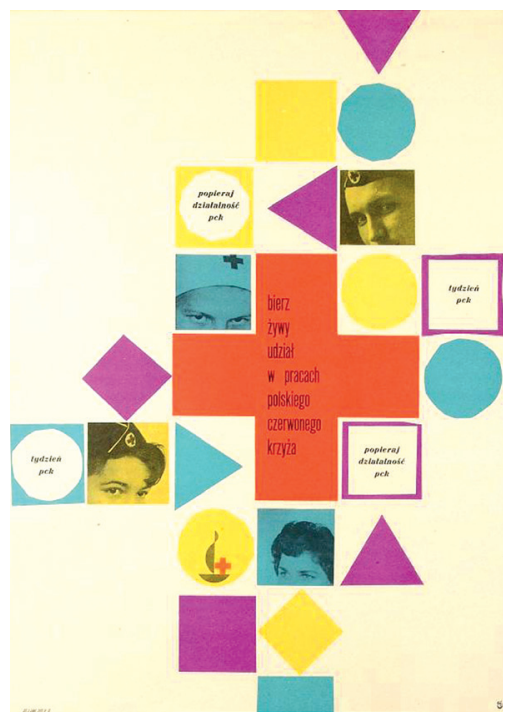

FIG. 20. Roman Cieślewicz: Play an active role in the work of the Polish Red Cross, 1962

Examples can be seen in the series of posters by Robert Sobczyński "Carelessness at work can lead to injuries" (published by CRZZ, 1961) and the later posters by Z. Osakowski: "Badly fitting shoes can cause injury".

The poster by another recognized artist, Rosław Szaybo "The blood of an honorary blood donor saved their lives" (published by WAG, commissioned by the polish Red Cross, 1961) presents a rare positive image of the poster's protagonist, in this case an honorary blood donor. He appears only as a shadow behind the running and laughing children, but his subtly suggested silhouette radiates heroism and valour. Interesting is the simple synthetic way in which the hero has been given positive features: the upright posture, neatly trimmed hair, and the head proudly held high, but slightly turned away. This

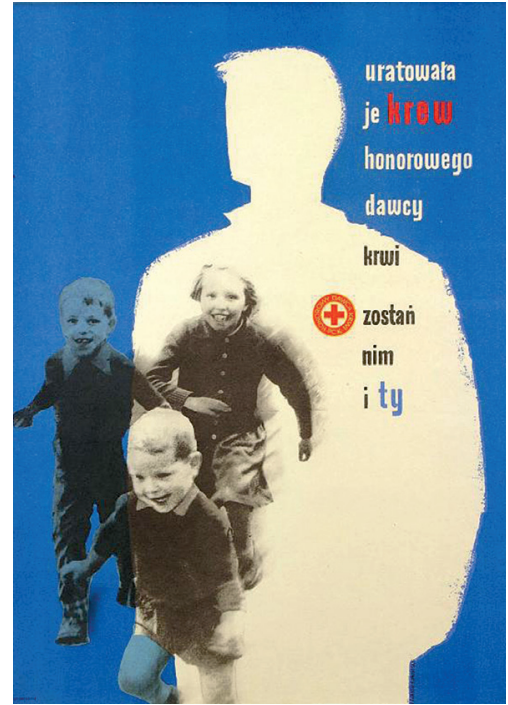

FIG. 19. Rosław Szaybo, Jerzy Zagórski: The blood of an honorary blood donor saved their lives, 1961

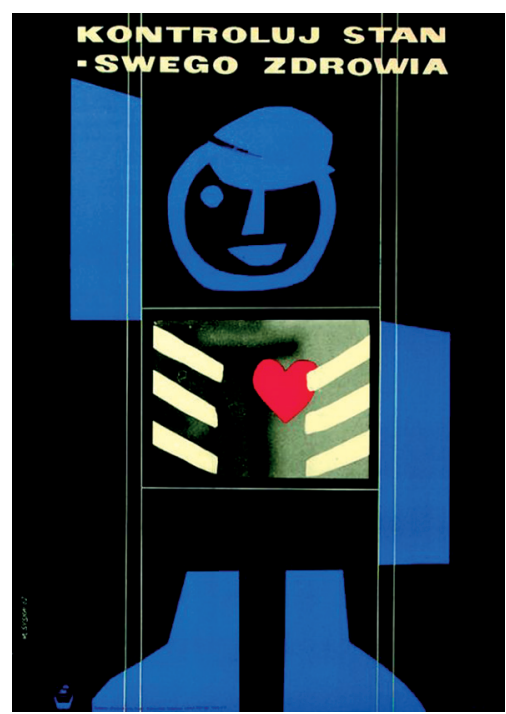

FIG. 21. Maria Syska: Monitor your state of health, 1962

time the white silhouette is intended to inspire trust and admiration.

Roman Cieślewicz's poster "Play an active role in the work of the Polish Red Cross" (published by WAG, commissioned by the Polish Red Cross, 1962) uses purely graphic means to make the desired impression on the viewer. Sometimes pleasant colours and a modern composition are sufficient to lend a positive connotation. Honorary blood donors and volunteers are the new heroes in an era of rationalism.

Similarly, Maria Syska's poster "Monitor your state of health" (published by CRZZ, 1962) in a mild tone encourages people to take medical tests. A few effects introduced on the photograph's negative and a simple drawing lend this call for periodic health examinations a sympathetic tone. 


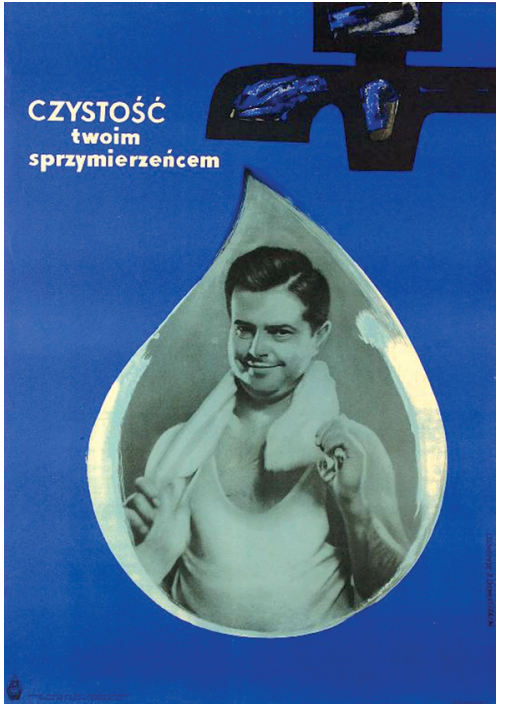

FIG. 22. Władysław Przystański: Cleanliness is your ally, 1963

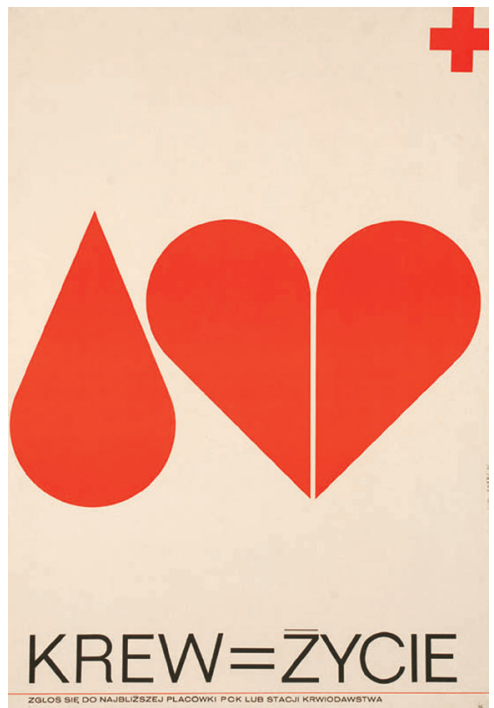

FIG. 24. Marek Freudenreich: Blood = Life, 1967

Finally, hygiene is encouraged by a cheerful, elegant man in Wladysław Przystański's poster "Cleanliness is your ally" (published by CRZZ, 1963).

From a certain point in time, posters that were more graphic than pictorial began to appear. A kind of pioneer in this respect is the poster by Mieczysław Bukowczyk "Protect your eyes" (published by CRZZ, 1964) with its vibrating pattern consisting of just a repeated message in various fonts. This process is one he repeated in subsequent designs.

The posters of Marek Freudenreich "Keep the noise down - noise is dangerous to health" (published by WAG, 1967) and "Blood = Life" (published by the Polish Red Cross, 1967) present a totally new way of thinking about graphics, less associated with the Polish school of

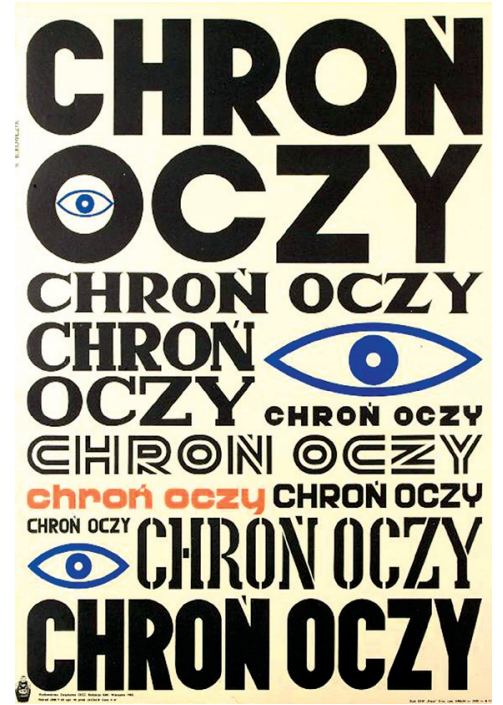

FIG. 23. Mieczysław Bukowczyk: Protect your eyes, 1964

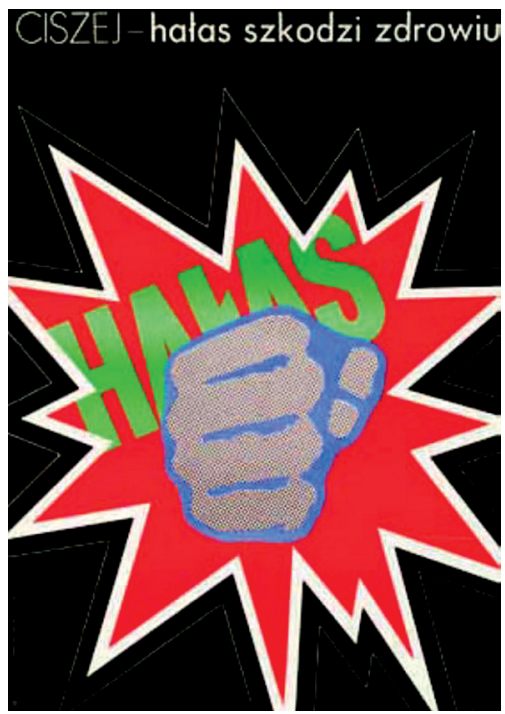

FIG. 25. Bronisław Zelek: Keep the noise down - noise is dangerous to health, 1969

poster, more with what was happening in contemporary graphic design. His graphic drop of blood combines with and helps create the universally recognised sign of a heart, thus associating blood donation with mercy.

Maintained in a similar graphic style is Bronisław Zelek's pop-art poster "Keep the noise down - noise is dangerous to health" (published by WAG, 1969).

On the other hand, appearing as it were on the side-lines of the main trends, and endearing in their graphic simplicity and mild sentimentality, are Leszek Hołdanowicz's posters, such as "Did you know that tuberculosis is a curable disease?" (published by WAG, 1964) and those of Danuta Żukowska: "Not even a drop of alcohol" (published by WAG, 1967) and "Protecting your lungs protects your heart" (published by WAG, 


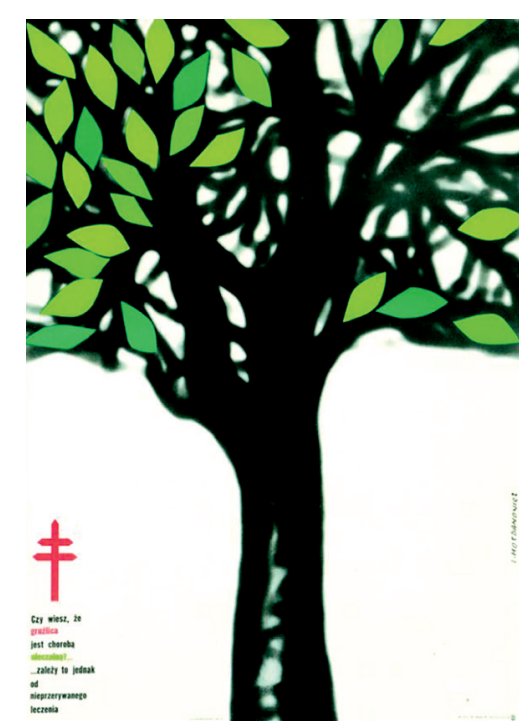

FIG. 26. Leszek Hołdanowicz: Did you know that tuberculosis is a curable disease?, 1964

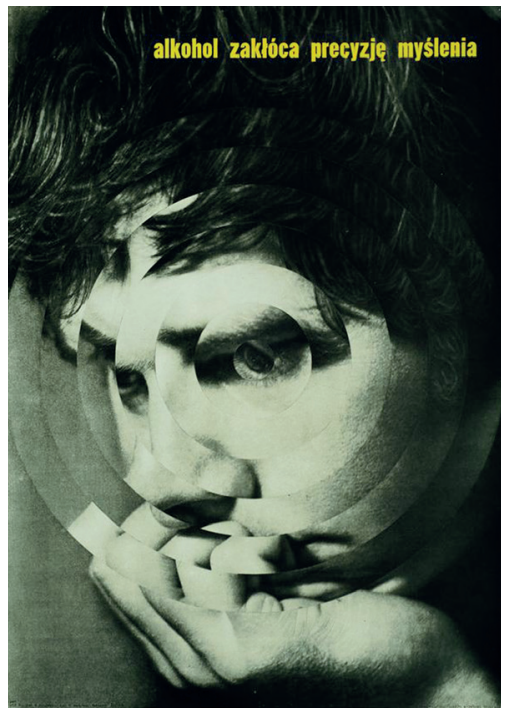

FIG. 28. Marek Freudenrich: Alcohol interferes with precision of thinking, 1970

commissioned by the Social Committee for the Eradication of Tuberculosis and Lung Diseases, 1974).

Beginning in the late ' 60 s and early ' 70 s, a change can clearly be seen in the health-related poster. Instead of campaigns warning against epidemics and accidents at work, there is a clearly observed current of campaigning against diseases that are largely social, such as alcoholism, venereal disease, or smoking. In the following years there appeared completely new challenges, and with them a whole new form of social activity. Campaigns against inebriation, smoking, and drugs, or those to encourage voluntary blood donations - each of these issues posed new challenges for poster designers.

The campaign against the spread of VD set poster designers an exceptionally difficult task, namely how
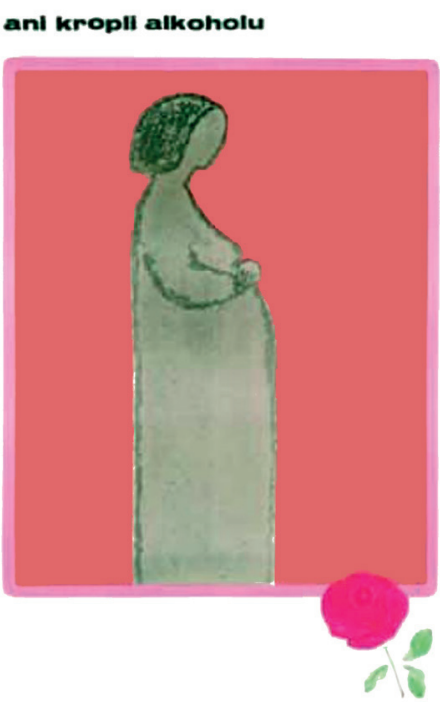

FIG. 27. Danuta Żukowska: Not even a drop of alcohol, 1967

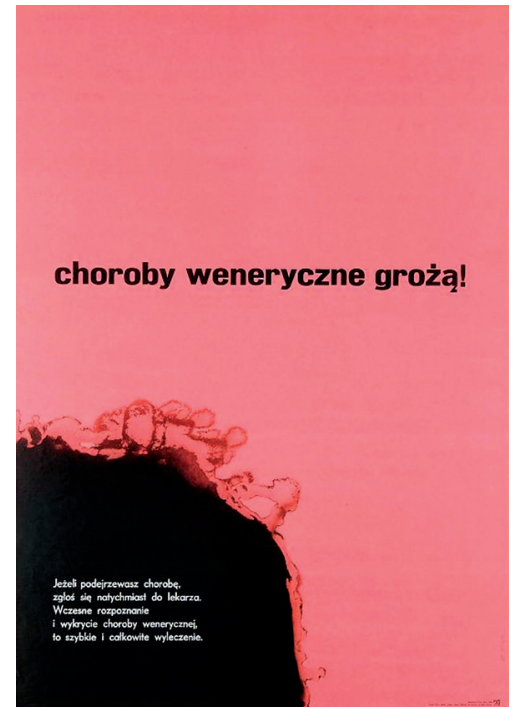

FIG. 29. Bronisław Zelek: Venereal diseases are a threat to health!, 1968

to warn the public about venereal diseases in a simple and easily assimilated way, without resorting to obscenity and vulgarity. Many artists used allusion, suggestion, and understatement, a method they had developed in times of greater political censorship. Modern graphics often permitted such a cold, clinical allusion. Sometimes this visual suggestion had a greater impact than concrete data. Bronisław Zelek's poster "Venereal diseases are a threat to health!" (published by WAG, 1968) is based on the use of merely suggestive colours and forms: an unhealthy, greyish pink and a photographic image scorched at the bottom to lend the effect of a micro-organism and viruses as seen under a microscope, or pathological organic formations, associating sexuality with disease. 


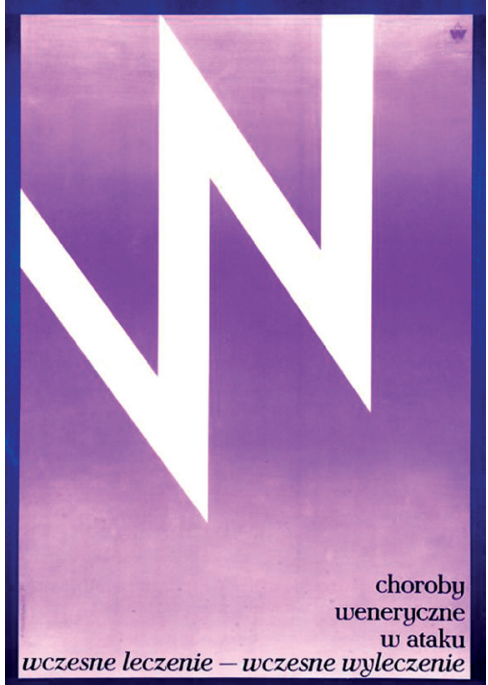

FIG. 30. Leszek Hołdanowicz: Venereal diseases pose a threat, 1971

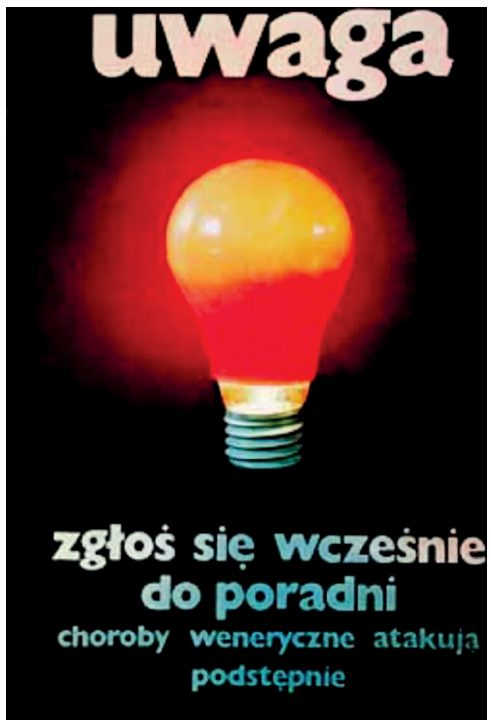

FIG. 31. Marek Freudenreich: Beware! Don't wait to report to a clinic, 1973

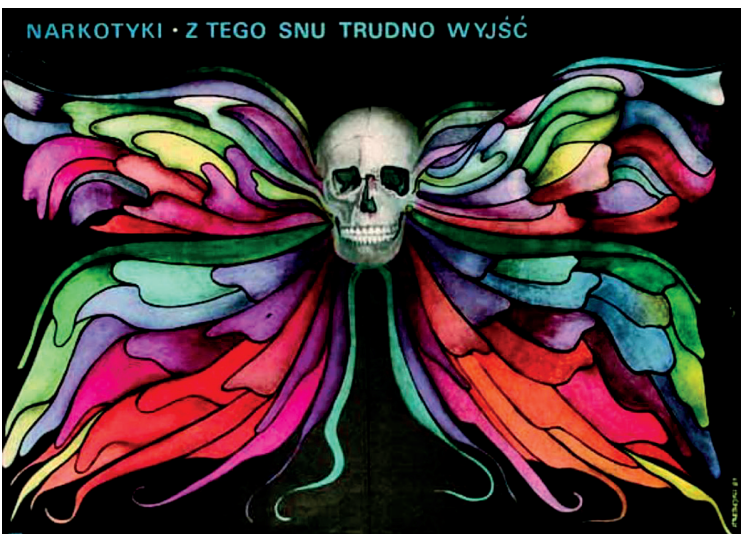

FIG. 32. Wiesław Strebejko: Narcotics - a nightmare hard to awaken from, 1981
Leszek Hołdanowicz's "Venereal diseases pose a threat" (published by WAG, commissioned by the Medical Academy's Venereology Institute, 1971) uses the full graphic potential of the one letter "W" (the Polish equivalent of the $\mathrm{V}$ in VD), making it a dangerous zigzag, which in human consciousness is associated with the image of lightning or a snake (both phenomena being seen as dangerous). The background, maintained in a cool shade of fuchsia, intensifies the poster's expression.

Marek Freudenreich's poster "Beware! Don't wait to report to a clinic" (published by WAG, commissioned by the Medical Academy's Venereology Institute, 1973) uses an economical allusion. The photography of a glowing red light bulb suggests the initial symptoms of venereal diseases: blemishes and itchy skin. Such a suggestive image, legible mainly for those in the know, avoids being too blunt and literal.

In the ' 80 s a new threat - drug addiction - became officially recognised. This was the first of the many diseases associated with modern civilisation, which in time also came to affect our society, such as work stress or AIDS. In such cases it became increasingly difficult to get a positive message over to the public. As researchers have noted, despite extensive campaigns, their impact has been minimal or else had the opposite effect. Often the designers, not knowing too much about the subject, confined themselves to stereotypes. A striking example is the poster by Wiesław Strebejko "Narcotics - a nightmare hard to awaken from" (published by KAW - the National Publishing Agency, 1981). Maintained in a dreamy Art Nouveau style, this poster is aimed as a warning, but its composition and expression are so ambiguous that they become disturbingly attractive or even fascinating. Thus, it may constitute a perverse, tantalising encouragement or even one that glorifies the complicated mental state that is drug addiction.

\section{OBSERVATIONS AND CONCLUSIONS}

In the Polish People's Republic there were few social organisations or citizens' initiatives. A large part of the pre-war tradition of cooperatives had been lost. Social campaigns were centralised and institutionalised. They usually only operated theoretically, as they had little impact or had quite the opposite effect. Perhaps this was due to people's deep-rooted distrust of state institutions, which derived from the nineteenth century. Poles treated the state and all its trappings as an oppressive machine imposed on them, while all campaigns controlled by the powers-that-be aroused suspicion.

And yet, some civil initiatives did take place. The social poster can be seen as a prototype of social campaigns. That social activity mainly led to visual persuasion. Thanks to this, there arose a strange virtual world of visual stereotypes. On the one hand a pleasant, rational world of abstainers, shock-workers, healthy children, and hygienists. On the other, the real world of drunken farmers and exhausted labourers, neglected and often 
starving children, and a continuous shortage of basic products. The real world lived in the shadow of the official discourse, sometimes literally, with contesting youth gathering in the shadow of a large socialist banner at Warsaw's Central Railway Station. As we know, in the Polish People's Republic it was as if two social systems functioned - the official and unofficial, two currents of life, dependent on each other like Siamese twins.

One other phenomenon is worth mentioning. In socialist Poland, an unusual trend emerged in applied art circles. The signed original, or artistic poster, often associated with the so-called Polish school of poster, is to this day the kind of phenomenon that could only arise in a similar, somewhat unusual social system [14]. And its influence suddenly became very broad. It apparently met the expectations of both the public and the artists. The artistic poster is unique in many ways, but here we are interested mostly in its subversive approach to the visual stereotype. Artistic posters were distinguishable by their sophisticated artistic style, as well as their surprising intellectual content. Unique, amusing, or ambiguous associations deconstructed existing stereotypes $[15,16]$. The conventional poster acts, even if subconsciously, as a stereotype. In contrast, the signed original poster broke down those stereotypes and achieved its aim by a certain degree of surprise, by exceeding the limits of the obvious, by a combination of various semantic fields, and finally, by means of a kind of paradox.

Social initiatives and government campaigns were aimed at raising the public's awareness through a change in cultural stereotypes. As it turned out, there was a greater response to works that were artistically inferior, often kitschy, accurate in their detail, and skilfully making use of stock models. Why did this happen? This is a topic for more extensive research. Now we can only draw some hypotheses. Inferior art, so-called kitsch, generates a greater emotional response, has a greater effect on the subconscious, and often has a more powerful social impact - perhaps due to close symbiosis with popular culture, a more faithful reflection of the nature of an era, and deeper fusion with the everyday life of its recipients. Works of "high" art, refined in their artistry, are a quality unto themselves. They function in their own closed, virtual world of symbolic values that they themselves have produced. To a large extent, they serve only as a symbolic accumulation of capital.

\section{DISCLOSURES}

Author reports no conflict of interest.

\section{References}

1. Foucault M. Philosophy, history, politics. Wydawnictwo Naukowe PWN, Warszawa, Wrocław 2000.

2. Godlewski G (ed.). Wiedza o kulturze. Część 1: wprowadzenie do wiedzy o kulturze: zagadnienia i wybór tekstów. Wydawnictwa Uniwersytetu Warszawskiego, Warszawa 1988.
3. Goffman E. The Presentation of Self in Everyday Life. KR Publishing House, Warszawa 2000; 104.

4. Barthes R. Mythologies. Aletheia, Warszawa 2008; 240.

5. Barthes R. Mitologie. $2^{\text {nd }}$ ed. Aletheia, Warszawa 2000.

6. Komorowski T. Plakat w propagandzie BHP. Instytut Wydawniczy CRZZ, Warszawa 1975.

7. Współczesne polskie drukarstwo i grafika książki. Mały słownik encyklopedyczny. Ossolineum, Wrocław 1982.

8. Noszczyk W. Zarys dziejów medycyny w Polsce. Tom 3. Wydawnictwo Lekarskie PZWL, Warszawa 2016.

9. Strączek T (ed.). 15 lat PCK w Polsce Ludowej. Spółdzielnia Pracy „Znak”, Warszawa 1959.

10. Zatoński W, Zatoński M. Health in the Polish People’s Republic. J Health Inequal 2016; 2: 7-16.

11. Skinner Burrhus Frederic: Behawioryzm. Gdańskie Wydawnictwo Psychologiczne, Sopot 2013.

12. Bąbel P, Ostaszewski P (eds.). Modern behavioural psychology. Jagiellonian University, Krakow 2008; 8.

13. Plakaty z kolekcji Centralnego Instytutu Ochrony Pracy - Państwowego Instytutu Badawczego. Praca zbiorowa. Wydawnictwo CIOP - BIP, Warszawa 1972.

14. Spiegel K (ed.). Muzeum ulicy. Wydawnictwo Krupski i S-ka, Warszawa 1996.

15. Schubert Z. Mistrzowie plakatu i ich uczniowie. Przedsiębiorstwo Wydawnicze Rzeczpospolita, Warszawa 2008.

16. Dydo K. Mistrzowie polskiej sztuki plakatu. Buffi, Bielsko-Biała 1995. 